\title{
Integrasi Pembelajaran Active Learning dan Internet-Based Learning dalam Meningkatkan Keaktifan dan Kreativitas Belajar
}

\author{
Mukhlison Effendi \\ STAIN Ponorogo \\ Email: ef.muikhlison@yahoo.co.id
}

\begin{abstract}
The learning process in higher education can use constructivist learning strategies for activeness and creativity of students. This study aimed to describe the integration of active learning and internet-based learning and to explain the factors supporting and inhibiting. From the observation data, interviews and documentation of the 31 students of the Department of Teacher Education for Islamic Primary Education (PGMI) and the lecturer of STAIN Ponorogo can be seen that the integration of active learning and Internetbased learning can enhance the activeness and creativity of student learning in the course. Factors supporting this result are the application of learning strategies, giving clear guidance, student learning motivation high and the availability of learning facilities and infrastructure. The factors that inhibit is the limited time, the dominance of smart students and unpreparedness of students receiving new material.
\end{abstract}

Keywords: active learning, internet-based learning, activeness, creativity.

\begin{abstract}
Abstrak
Proses pembelajaran di perguruan tinggi dapat menggunakan strategi pembelajaran konstruktivistik untuk keaktifan dan kreativitas mahasiswa. Penelitian ini ditujukan untuk mendeskripsikan integrasi active learning daninternet-based learning untuk menjelaskan faktor pendukung dan penghambatnya. Dari data observasi, interview dan dokumentasi terhadap 31 mahasiswa Program Studi Pendidikan Guru Madrasah Ibtidaiyah (PGMI) dan dosen STAIN Ponorogo dapat diketahui bahwa integrasi active learning dan internet-based learning dapat meningkatkan keaktifan dan kreativitas belajar mahasiswa di program studi tersebut. Faktor yang mendukung hasil ini adalah penerapan strategi pembelajaran, pemberian pengarahan yang jelas, motivasi belajar mahasiswa yang tinggi dan tersedianya sarana dan prasarana pembelajaran. Adapun faktor yang menghambat adalah keterbatasan waktu, dominasi mahasiswa pintar dan ketidaksiapan mahasiswa menerima materi baru.
\end{abstract}

Kata kunci: active learning, internet-based learning, keaktifan, kreativitas. 


\section{A. Pendahuluan}

Pembelajaran merupakan proses interaksi baik antara pendidik dengan peserta didik,peserta didik dengan peserta didik,maupun peserta didik dengan lingkungannya yang dapat merangsang peserta didik untuk belajar. Melalui proses interaksi, kemampuan peserta didik akan berkembang baik mental maupun intelektualnya.

Model pembelajaran di pendidikan tinggi masih cenderung dominan menggunakan strategi pembelajaran exposition atau ekspositori. Dalam strategi pembelajaran exposition,bahan pelajaran disajikan kepada peserta didik dalam bentuk jadi dan peserta didik dituntut untuk menguasai bahan tersebut. Akibatnya, mahasiswa menjadi cukup pasif tidak ada inisiatif untuk berpartisipasi dalam proses perkuliahan karena kurang adanya kondisi yang memungkinkan mahasiswa membangun sendiri pengetahuannya. Keberanian mahasiswa didik untuk bertanya,mengajukanpendapat,berdiskusisepertinyatelah"terpasun geoleh tradisi dosen yang mendominasi perkuliahan.

Keaktifan peserta didik dalam proses pembelajaran akan menyebabkan interaksi yang tinggi antara pendidik dengan peserta didik atau dengan peserta didik itu sendiri. Hal ini akan mengakibatkan suasana kelas menjadi segar dan kondusif, di mana masing-masing peserta didik dapat melibatkan kemampuannya semaksimal mungkin. Oleh karena itu, keaktifan belajar siswa merupakan unsur dasar yang penting bagi keberhasilan proses pembelajaran.

Dalam kegiatan pembelajaran peserta didik tidak hanya dituntut keaktifannya saja tapi juga kreativitasnya, karena kreativitas dapat menciptakan situasi yang baru, tidak monoton dan menarik sehingga siswa akan lebih terlibat dalam kegiatan pembelajaran. Kreativitas dipandang sebuah proses mental. Daya kreativitas menunjuk pada kemampuan berpikir yang lebih orisinal dibanding dengan kebanyakan orang lain. Gagasan-gagasan yang kreatif, tidak muncul begitu saja, untuk dapat menciptakan sesuatu yang bermakna dibutuhkan persiapan. Masa seorang anak duduk di bangku sekolah termasuk masa persiapan ini karena mempersiapkan seseorang agar dapat memecahkan masalah-masalah.

Program Studi PGMI merupakan salah satu program studi terfavorit di STAIN Ponorogo yang memiliki visi sebagai pusat pendidikan dan pengembangan calon Guru MI/SD yang 
kompeten. Misi dari Program studi PGMI adalah; 1) melaksanakan proses pendidikan dan pembelajaran dalam bidang keguruan dan pendidikan Tingkat MI/SD secara profesional; 2) Mengembangkan ilmu kependidikan yang berkaitan dengan proses pembelajaran di MI/SD secara proporsional, dan; 3) Menciptakan iklim akademik yang Islami. Dalam rangka mencapai visi misi tersebut, mahasiswa diharapkan aktif dalam proses pembelajaran dan selalu mengembangkan pemikiran yang kreatif.

Dalam upaya pengembangan keaktifan dan kreativitas mahasiswa, diperlukan inovasi baru dalam pembelajaran yang relevan dengan keadaan mahasiswa saat ini. Proses pembelajaran dapat menggunakan strategi-strategi pembelajaran konstruktivistik yang berpotensi memberdayakan keaktifan dan kreativitas seperti model pembelajaran aktif (active learning) yang terintegrasi dengan pembelajaran berbasis internet (internet-based learning).

Pembelajaran aktif (active learning) pada dasarnya merupakan salah satu bentuk atau jenis dari pendekatan pembelajaran yang berorientasi pada aktivitas peserta didik. Pembelajaran berorientasi pada aktivitas peserta didik mengandung Pengertian bahwa sistem pembelajaran menempatkan peserta didik sebagai subyek didik yang aktif dan telah memiliki ke siapan untuk belajar. Active learning menjadikan peserta didik sebagai subyek belajar dan berpotensi untuk meningkatkan kreativitas atau lebih aktif dalam setiap aktivitas pelajaran yang diberikan, baik di dalam maupun di luar.

Dalam strategi ini peserta didik diarahkan untuk belajar aktif dengan cara menyentuh (touching), merasakan (feeling) dan melihat (looking) langsung serta mengalami sendiri sehingga pembelajaran lebih bermakna dan cepat dimengerti oleh peserta didik dan pendidik dalam hal ini dituntut juga untuk memotivasi peserta didik dan memberikan arahan serta menyediakan prasarana lengkap.

Pembelajaran berbasis internet merupakan salah satu manifestasi e-learning yang paling populer, yang menawarkan berbagai keuntungan seperti kesempatan belajar yang lebih fleksibel tanpa terikat ruang dan waktu, mempermudah masyarakat mengakses pendidikan, memperkaya materi pembelajaran, menghidupkan proses pembelajaran, membuat proses pembelajaran lebih terbuka, meningkatkan efektivitas pembelajaran, serta mendukung siswa untuk belajar mandiri. Pembelajaran berbasis internet dalam hal ini e-learning merupakan 
dasar dan konsekuensi logis dari perkembangan teknologi informasi dan komunikasi.

Dengan e-learning, peserta didik tidak perlu duduk dengan manis di ruang kelas untuk menyimak setiap ucapan dari seorang guru secara langsung. E-learning juga dapat mempersingkat jadwal target waktu pembelajaran, dan tentu saja menghemat biaya yang harus di keluarkan oleh sebuah program studi atau program pendidikan. Bagi Mahasiswa Prodi PGMI, setiap mata kuliah adalah salah satu mata kuliah yang sangat penting yang bertujuan untuk membekali mahasiswa calon S1 PGMI agar memiliki kompetensi menjadi pendidik di sekolah dasar.

Oleh karena itu, guna mempersiapkan calon S1 PGMI yang profesional, dosen harus mengembangkan kreativitas yang ada dalam diri mahasiswa dengan penerapan model pembelajaran yang sesuai. Berdasarkan penjelasan di atas, peneliti tertarik untuk memotret integrasi pembelajaran active learning dan internet-based learning pada pembelajaran dalam meningkatkan keaktifan dan kreativitas mahasiswa Prodi PGMI di STAIN Ponorogo.

\section{B. Telaah Pustaka}

1. Pembelajaran

Pembelajaran adalah suatu kegiatan yang dilakukan secara sadar dan sengaja. Adapun tujuan pembelajaran dalam bukunya Sugandi adalah membantu para siswa agar memperoleh berbagai pengalaman, dan dengan pengalaman itu tingkah laku yang dimaksud meliputi pengetahuan, keterampilan, dan nilai atau norma yang berfungsi sebagai pengendali sikap dan prilaku siswa

Dalam melaksanakan kegiatan pembelajaran tentunya banyak faktor yang mempengaruhi berhasil atau tidaknya. Faktor yang mempengaruhi belajar dibedakan menjadi dua golongan, yaitu faktor intern dan faktor ekstern. Faktor intern adalah faktor yang ada dalam diri individu yang sedang belajar, sedangkan faktor ekstern adalah yang berada di luar individu. Yang termasuk faktor Intern antara lain: faktor-faktor jasmaniah (faktor kesehatan dan cacat tubuh); psikologis (inteligensi, perhatian, minat, bakat, motif, kematangan, dan kesiapan); dan kelelahan (kelelahan jasmani dan rohani). Sedang yang termasuk faktor ekstern antara lain faktor keluarga (cara orang tua mendidik, relasi antar anggota 
keluarga, suasana rumah, keadaan ekonomi keluarga, Pengertian orang tua, dan latar belakang kebudayaan); sekolah (metode mengajar, kurikulum, disiplin, media pembelajaran, standar pelajaran di atas ukuran, keadaan gedung, metode mengajar, dan tugas rumah); dan faktor masyarakat (kegiatan siswa dalam masyarakat, media massa, teman bergaul, dan bentuk kehidupan masyarakat).

2. Pembelajaran Aktif (Active Learning)

Pembelajaranactivelearningpadadasarnyabukansebuahide yang baru lagi. Gagasan pembelajaran active learning telah ada sejak masa Socrates dan merupakan salah satu penekanan utama di antara para pendidik progresif seperti John Dewey yang memandang bahwa secara alami belajar merupakan proses yang aktif.

Meyersand Jones menyatakan bahwa "activelearning derives from two basic assumptions: (a) that learning is by its very nature an active process and (b) that different people learn in differentways. 'Dengan kata lain, bahwa pembelajaran pada dasarnya adalah pencarian secara aktif pengetahuan dan setiap orang belajar dengan cara yang berbeda.

Pembelajaran aktif (active learning) adalah suatu proses pembelajaran dengan maksud untuk memberdayakan peserta didik agar belajar dengan menggunakan berbagai cara/strategi secara aktif. Dalam hal ini proses aktivitas pembelajaran didominasi oleh peserta didik dengan menggunakan otak untuk menemukan konsep dan memecahkan masalah yang sedang dipelajari, di samping itu juga untuk menyiapkan mental dan melatih keterampilan fisiknya.

Cara memberdayakan peserta didik tidak hanya dengan menggunakan strategi atau metode ceramah saja, sebagaimana yang selama ini digunakan oleh para pendidik (guru) dalam proses pembelajaran. Mendidik dengan ceramah berarti memberikan suatu informasi melalui pendengaran, yang hanya bisa dicerna otak siswa 20\%. Padahal informasi yang dipelajari siswa bisa saja dari membaca(10\%), melihat $(30 \%)$, melihat dan dengar $(50 \%)$, mengatakan $(70 \%)$, mengatakan dan melakukan $(90 \%)$. Hal ini sesuai dengan pendapat seorang filosof Konfusius bahwa "Apa yang saya dengar, saya lupa" "Apa yang saya lihat, saya ingat" "Apa yang saya lakukan, saya paham". 
Ketika ada informasi yang baru, otak manusia tidak hanya sekedar menerima dan menyimpan. Akan tetapi otak manusia akan memproses informasi tersebut sampai dapat dicerna dan baru kemudian disimpannya. Karena itu jika ada sesuatu yang baru, otak akan bertanya "pernahkah aku mendengar, melihat, mengalami sebelumnya, kapan dan di manakah kira-kira hal itu aku dengar, lihat dan ku alami lalu di manakah hal itu aku simpan?" Manusia dengan potensi dasar yang ia miliki termasuk otak tersebut perlu diaktifkan, sehingga berfungsi semaksimal mungkin melalui proses belajar yang ia lakukan.

Berdasarkan penjelasan di atas, dapat disimpulkan bahwa pembelajaran aktif adalah segala bentuk pembelajaran yang memungkinkan mahasiswa berperan secara aktif dalam proses pembelajaran itu sendiri baik dalam bentuk interaksi antar mahasiswa maupun mahasiswa dengan dosen dalam proses pembelajaran tersebut.

Menurut Bonwell pembelajaran aktif memiliki Karakteristik sebagai berikut:

a. Penekanan proses pembelajaran bukan pada penyampaian informasi oleh pengajar melainkan pada pengembangan keterampilan pemikiran analitis dan kritis terhadap topik atau permasalahan yang dibahas,

b. Mahasiswa tidak hanya mendengarkan kuliah secara pasif tetapi mengerjakan sesuatu yang berkaitan dengan materi kuliah,

c. Penekanan pada eksplorasi nilai-nilai dan sikap-sikap berkenaan dengan materi kuliah,

d. Mahasiswa lebih banyak dituntut untuk berpikir kritis, menganalisa dan melakukan evaluasi,

e. Umpan-balik yang lebih cepat akan terjadi pada proses pembelajaran.

Di samping Karakteristik tersebut di atas, secara umum suatu proses pembelajaran aktif mempunyai ciri-ciri sebagai berikut:

a. Situasi kelas menantang peserta didik melakukan kegiatan belajar secara bebas tapi terkendali.

b. Pendidik tidak mendominasi pembicaraan tetapi lebih banyak memberikan rangsangan berpikir kepada peserta didik untuk memecahkan masalah. 
c. Pendidik menyediakan dan mengusahakan sumber belajar bagi peserta didik,bisa sumber tertulis, sumber manusia, misalnya peserta didik itu sendiri menjelaskan permasalahan kepada peserta didik lainnya, berbagai media yang diperlukan, alat bantu pengajaran, termasuk pendidik sendiri sebagai sumber belajar.

d. Kegiatan belajar peserta didik bervariasi, ada kegiatan yang sifatnya bersama-sama dilakukan oleh semua peserta didik, ada kegiatan belajar yang dilakukan secara kelompok dalam bentuk diskusi dan ada pula kegiatan belajar yang harus dilakukan oleh masing-masing peserta didik secara mandiri. Penetapan kegiatan belajar tersebut diatur oleh guru secara sistematik dan terencana.

e. Pendidik menempatkan diri sebagai pembimbing semua peserta didik yang memerlukan bantuan manakala mereka menghadapi persoalan belajar.

f. Situasi dan kondisi kelas tidak kaku terikat dengan susunan yang mati, tapi sewaktu-waktu diubah sesuai dengan kebutuhan peserta didik

g. Belajar tidak hanya dilihat dan diukur dari segi hasil yang dicapai peserta didik tapi juga dilihat dan diukur dari segi proses belajar yang dilakukan siswa.

h. Adanya keberanian peserta didik mengajukan pendapatnya melalui pertanyaan atau pernyataan gagasannya, baik yang diajukan kepada pendidik maupun kepada peserta didik lainnya dalam pemecahan masalah belajar.

i. Pendidik senantiasa menghargai pendapat peserta didik terlepas dari benar atau salah. Bahkan pendidik harus mendorong peserta didik agar selalu mengajukan pendapatnya secara bebas.

Agar proses pembelajaran active learning bisa berjalan dengan baik, maka pendidik sebagai penggerak belajar peserta didik dituntut untuk menggunakan dan menguasai strategi pembelajaran active learning . Ada banyak strategi pembelajaran aktif dari mulai yang sederhana sampai dengan yang rumit. Beberapa jenis strategi pembelajaran tersebut antara lain adalah :

a. Poster comment (mengomentari gambar) yaitu suatu strategi yang digunakan pendidik dengan maksud 
mengajak peserta didik untuk memunculkan ide apa yang terkandung dalam suatu gambar. Gambar tersebut tentu saja berkaitan dengan pencapaian suatu kompetensi dalam pembelajaran. Dengan strategi ini peserta didik diharapkan dapat memberi masukan berupa pendapat/ide yang bervariasi karena setiap pikiran manusia itu berbeda-beda, dengan berbagai macam pendapat dari peserta didik tersebut akan dapat ditarik benang merahnya tentang inti pokok dari materi yang diajarkan.

b. Index Card Match (mencari pasangan jawaban) yaitu suatu strategi yang digunakan pendidik dengan maksud mengajak peserta didik untuk menemukan jawaban yang cocok dengan pertanyaan yang sudah disiapkan.

c. Active debate (debat aktif),strategi ini mendorong pemikiran dan perenungan terutama kalau peserta didik diharapkan memertahankan pendapat yang bertentangan dengan keyakinannya sendiri. Debat bisa menjadi satu metode berharga yang dapat mendorong pemikiran dan perenungan, terutama kalau peserta didik diharapkan dapat mempertahankan pendapat yang bertentangan dengan keyakinan mereka sendiri. Strategi ini dapat diterapkan kalau guru hendak menyajikan topik yang menimbulkan prokontra dalam mengungkapkan argumentasinya. Banyak kecakapan hidup yang dapat dilatih dengan strategi ini antara lain kemampuan berkomunikasi dan mengomunikasikan gagasannya kepada orang lain.

d. Everyone is Teacher Here (semua adalah pendidik) yaitu strategi yang digunakan oleh pendidik dengan maksud meminta peserta didik untuk semuanya berperan menjadi narasumber terhadap sesama temannya di kelas belajar. Strategi ini bertujuan untuk memberikan kesempatan yang sama kepada setiap peserta didik untuk berperan sebagai guru bagi kawannya. Dengan ini diharapkan agar peserta didik yang pasif dapat ikut terlibat dalam pembelajaran aktif.

e. Team Quiz, strategi ini mendorong siswa untuk aktif dalam kelompok untuk membuat pertanyaan serta jawaban sesuai dengan kompetensi yang diharapkan.

f. Role Playatau bermain peran adalah strategi pembelajaran sebagai bagian dari simulasi yang diarahkan untuk 
mengkreasi peristiwa sejarah, mengkreasi peristiwaperistiwa aktual, atau kejadian-kejadian yang mungkin muncul pada masa mendatang. Topik yang dapat diangkat untuk role play misalnya memainkan peran sebagai juru kampanye suatu partai atau gambaran keadaan yang mungkin muncul di masyarakat.

g. Peer Teaching,merupakan latihan mengajar yang dilakukan oleh mahasiswa kepada teman-teman calon guru. Selain itu peerteaching merupakan kegiatan pembelajaran yang dilakukan seorang siswa kepada siswa lainnya dan salah satu siswa itu lebih memahami materi pembelajaran.

h. Student-led Review Session. Strategi ini digunakan untuk memberikan peran kepada mahasiswa sebagai pengajar. Dosen hanya bertindak sebagai narasumber dan fasilitator. Strategi ini dapat digunakan pada sesi review terhadap materi kuliah. Pada bagian pertama dari kuliah kelompokkelompok kecil mahasiswa diminta untuk mendiskusikan hal-hal yang dianggap belum dipahami dari materi tersebut dengan mengajukan pertanyaan-pertanyaan dan mahasiswa yang lain menjawabnya. Kegiatan kelompok dapat juga dilakukan dalam bentuk salah satu mahasiswa dalam kelompok tersebut memberikan ilustrasi bagaimana suatu rumus atau metode digunakan. Kemudian pada bagian kedua kegiatan ini dilakukan untuk seluruh kelas. Proses ini dipimpin oleh mahasiswa dan dosen lebih berperan untuk mengklarifikasi hal-hal yang menjadi bahasan dalam proses pembelajaran tersebut.

i. Jigsaw, yaitu strategi kerja kelompok yang terstruktur didasarkan pada kerjasama dan tanggungjawab. Kelebihan strategi ini adalah dapat melibatkan seluruh siswa dan setiap peserta didik memikul suatu tanggung jawab yang signifikan dalam kelompok.

j. Reading Guide (penuntun bacaan). Strategi ini digunakan pendidik dengan maksud mengajak peserta didik untuk mempelajari sesuatu dengan cara membaca suatu teks bacaan (buku, majalah, koran dan lain-lain) sesuai dengan materi bahasan.

k. Card Sort (menyortir kartu). Yaitu strategi yang digunakan oleh pendidik dengan maksud mengajak peserta didik 
untuk menemukan konsep dan fakta melalui klasifikasi materi yang dibahas dalam pembelajaran.

1. Concept Mapping (peta konsep). Suatu cara yang digunakan oleh pendidik dengan maksud meminta peserta didik untuk membuat konsep atau kata-kata kunci dari suatu pokok persoalan sebagai rumusan inti pelajaran.

m. Information Search (mencari informasi) yaitu suatu cara yang digunakan oleh guru dengan maksud meminta peserta didik untuk menjawab pertanyaan-pertanyaan yang diajukan baik oleh pendidik maupun peserta didik sendiri, kemudian mencari informasi jawabannya lewat membaca untuk menemukan informasi yang akurat.

n. Demonstration (Demonstrasi). Suatu presentasi yang dipersiapkan dengan hati-hati untuk memperlihatkan bagaimana berprilaku atau menggunakan suatu prosedur atau alat. Presentasi dilengkapi dengan penjelasan lisan dan atau alat visual, ilustrasi dan pertanyaan.

o. Think-Pair-Share, dengan cara ini mahasiswa diberi pertanyaan atau soal untuk dipikirkan sendiri kurang lebih 2-5 menit (think), kemudian mahasiswa diminta untuk mendiskusikan jawaban atau pendapatnya dengan teman yang duduk di sebelahnya (pair). Setelah itu, pengajar dapat menunjuk satu atau lebih mahasiswa untuk menyampaikan pendapatnya atas pertanyaan atau soal itu bagi seluruh kelas (share).

3. Pembelajaran Berbasis Internet (Internet-Based Learning)

Internet-based learning adalah segala pemanfaatan atau penggunaan teknologi internet dan Wet untuk menciptakan pengalaman pembelajaran. Dengan kata lain, internet-based learning merupakan suatu jenis belajar mengajar yang memungkinkan tersampaikannya bahan ajar ke siswa dengan menggunakan media internet.

Rosenberg menekankan bahwa internet-based learning merujuk pada penggunaan teknologi internet untuk mengirimkan serangkaian solusi yang dapat meningkatkan pengetahuan dan keterampilan. Internet-based learning merupakan bentuk manifestasi dari konsep e-learning. Hal ini senada dengan Cambell yang intinya menekankan penggunaan internet dalam pendidikan sebagai hakikat $e$-learning. Bahkan Onno W. Menjelaskan bahwa istilah "e" atau 
singkatan dari elektronik dalam e-learning digunakan sebagai istilah untuk segala teknologi yang digunakan untuk mendukung usaha-usaha pengajaran lewat teknologi elektronik internet.

Adapun yang menjadi Karakteristik dari pembelajaran berbasis internet (internet-based learning), antara lain; a) Memanfaatkan jasa teknologi elektronik; di mana pendidik dan peserta didik, peserta didik dan sesama peserta didik atau dapat berkomunikasi dengan relatif mudah dengan tanpa dibatasi oleh hal-hal yang protokoler; b) Memanfaatkan keunggulan komputer (digital media andcomputernetworks); c) Menggunakan bahan ajar bersifat mandiri (self learning materials) disimpan di komputer sehingga dapat diakses oleh pendidik dan peserta didik kapan saja dan di mana saja bila yang bersangkutan memerlukannya; d) Memanfaatkan jadwal pembelajaran, kurikulum, hasil kemajuan belajar dan hal-hal yang berkaitan dengan administrasi pendidikan dapat dilihat setiap saat di komputer.

Manfaat pembelajaran berbasis internet (internet-based learning) menurut Bates (1995) dan Wulf (1996) terdiri atas 4 hal, yaitu; a) Meningkatkan kadar interaksi pembelajaran antara peserta didik dengan guru atau instruktur (enhance interactivity), (b) Memungkinkan terjadinya interaksi pembelajaran dari mana dan kapan saja (time and place flexibility); c) Menjangkau peserta didik dalam cakupan yang luas (potential to reach a global audience); d) Mempermudah penyempurnaan dan penyimpanan materi pembelajaran (easy updating of content as well as archivable capabilities).

Ada3(tiga) fungsi internet-based learning terhadapkegiatanpembelajarandidalamkelas,yaitu sebagai tambahan(suplemen),pelengkap(komplemen), atau pengganti (substitusi). Dikatakan berfungsi sebagai suplemen (tambahan),apabila peserta didik mempunyai kebebasan memilih, Apakah akan memanfaatkan materi e-learning atau tidak. Dalam hal ini, tidak ada kewajiban/keharusan bagi peserta didik untuk mengakses materi internet-based learning. Sebagai komplemen berarti materi e-learning diprogramkan untuk menjadi materi reinforcement (pengayaan) atau remedial bagi peserta didik di dalam mengikuti kegiatan pembelajaran konvensional. Materi internet-based learning juga dapat berfungsi sebagai enrichment, apabila kepada peserta didik yang dapat 
dengan cepat menguasai atau memahami materi pelajaran yang disampaikan guru secara tatap muka (fastlearners) diberikan kesempatan untuk mengakses materi internet-based learning yang memang secara khusus dikembangkan untuk mereka.

4. Keaktifan Belajar

Keaktifan berasal dari kata aktif yang berarti giat atau sibuk. Kata keaktifan juga bisa berarti dengan kegiatan dan kesibukan. Yang dimaksud dengan keaktifan di sini adalah bahwa pada waktu pendidik mengajar ia harus mengusahakan agar peserta didiknya aktif jasmani maupun rohani.

Dalam proses pembelajaran peserta didik dituntut untuk aktif, penilaian proses pembelajaran terutama melihat sejauh mana keaktifan peserta didik dalam mengikuti proses pembelajaran. Perihal tentang keaktifan belajar menurut Nana Sudjana di antaranya:

a. Turut serta dalam melaksanakan tugas belajarnya

b. Terlibat dalam pemecahan masalah

c. Bertanya kepada peserta didik lain atau kepada guru apabila tidak memahami persoalan yang dihadapinya

d. Berusaha mencari berbagai informasi yang diperlukan untuk pemecahan masalah

e. Melaksanakan diskusi kelompok sesuai petunjuk guru

f. Menilai kemampuan dirinya dan hasil-hasil yang diperolehnya

g. Melatih diri dalam memecahkan soal atau masalah sejenis

h. Kesempatan menggunakan atau menerapkan apa yang diperolehnya dalam menyelesaikan tugas atau persoalan yang dihadapi.

Berdasarkan beberapa pendapat di atas dapat disimpulkan bahwa keaktifan belajar adalah segala kegiatan yang dilakukan dalam proses pembelajaran yaitu proses interaksi (pendidik dan peserta didik) dalam rangka memperoleh hasil belajar berupa perpaduan antara aspek kognitif, afektif dan psikomotor.

Munir mengelompokkan keaktifan peserta didik ini menjadi beberapa aspek, antara lain yaitu; a) aktif secara jasmani seperti penginderaan, yaitu mendengar, melihat, mencium, merasa, dan meraba atau melakukan keterampilan jasmaniah; b) aktif berpikir melalui tanya jawab, mengolah 
dan mengemukakan ide, berpikir logis, sistematis, dan sebagainya; dan c) aktif secara sosial seperti aktif berinteraksi atau bekerjasama dengan orang lain .

5. Kreativitas Belajar

Pengertian kreativitas sudah banyak dikemukakan oleh para ahli berdasarkan pandangan yang berbeda-beda, seperti yang dikemukakan oleh Utami Munandar menjelaskan Pengertian kreativitas dengan mengemukakan beberapa perumusan yang merupakan kesimpulan para ahli mengenai kreativitas.

Pertama, kreativitas adalah kemampuan untuk membuat kombinasi baru berdasarkan data, informasi, atau unsur-unsur yang ada. Kedua, kreativitas (berpikir kreatif atau berpikir divergen) adalah kemampuan berdasarkan data atau informasi yang tersedia, menemukan banyak kemungkinan jawaban terhadap suatu masalah, di mana penekanannya adalah pada kuantitas, ketepatgunaan, dan keragaman jawaban. Ketiga secara operasional kreativitas dapat dirumuskan sebagai kemampuan yang mencerminkan kelancaran, keluwesan (fleksibilitas), dan orisinalitas dalam berpikir, serta kemampuan untuk mengelaborasi (mengembangkan, memperkaya, merinci) suatu gagasan.

\section{Telaah Penelitian Terdahulu}

Penelitian yang dilakukan oleh Puput Dwi Maret Tanti yang bertujuan untuk meningkatkan kreativitas belajar biologi siswa kelas XI A3 SMA Negeri 1 Ngemplak Boyolali melalui penerapan pembelajaran aktif (active learning) dengan metode Mind Map. Penelitian ini merupakan penelitian tindakan kelas yang dilaksanakan dalam dua siklus. Hasil penelitian menunjukkan bahwa pelaksanaan tindakan kelas melalui penerapan pembelajaran aktif (active learning) dengan metode Mind Map dapat meningkatkan kreativitas belajar biologi siswa kelas XI A3 SMA Negeri 1 Ngemplak Boyolali. Hal ini didasarkan pada hasil observasi, angket, dan wawancara. Rata-rata nilai persentase setiap indikator yang didapatkan dari hasil observasi kreativitas belajar siswa untuk siklus I sebesar $76 \%$ dan siklus II sebesar $84,67 \%$ (meningkat 8,67\%). Rata-rata nilai persentase setiap indikator dari angket kreativitas belajar siswa untuk siklus I 77,43\% dan siklus II $78,87 \%$ (meningkat 1,44\%). 
Selanjutnya, Tatmimatun Ni'mah, Triyono dan Joharman melakukan penelitian tentang Penerapan Metode Index Card Match untuk Meningkatkan Keaktifan dalam Pembelajaran IPS Siswa Kelas IV SD. Penelitian ini bertujuan: mendeskripsikan proses pembelajaran, keaktifan dalam pembelajaran IPS. Penelitian dilaksanakan dalam tiga siklus. Subjek penelitian ini adalah seluruh siswa kelas IV SD Negeri 1 Petanahan yang berjumlah 21 siswa. Sumber data berasal dari siswa, teman sejawat dan peneliti. Teknik pengumpulan data menggunakan observasi, dokumentasi dan tes. Validitas data menggunakan teknik triangulasi metode dan sumber. Analisis data yang digunakan dengan analisis kualitatif dan kuantitatif. Hasilnya menunjukkan bahwa penerapan metode index card match, dapat meningkatkan keaktifan siswa dalam pembelajaran IPS di kelas IV.

Donna Carolina melaksanakan penelitian tindakan kelas dengan memvariasikan metode active learning di kelas dengan $e$ learning (web). Subjek penelitian ini adalah siswa kelas X AP 1 SMK Negeri 2 Semarang. Rancangan kegiatan penelitian ini adalah siklus kegiatan yang terdiri dari tiga siklus. Instrumen pengumpulan data yang dalam penelitian ini adalah lembar observasi guru, siswa dan proses untuk mengukur kualitas iklim pembelajaran aktif dan tes untuk mengukur hasil belajar yang berlangsung tiap siklusnya. Hasil penelitian diperoleh rata-rata tingkat kualitas pembelajaran aktif yang tercipta pada siklus I sebesar $55.3 \%$, pada siklus II sebesar $73.27 \%$ dan pada siklus III mengalami peningkatan menjadi $86.82 \%$ dengan kategori sangat baik. Hasil analisis regresinya membuktikan pengaruh pembelajaran aktif terhadap hasil belajar dengan persamaan $\mathrm{Y}=$ $22.028+1.601 \mathrm{X}$ dengan nilai R2 0.857 dan nilai probabilitas FTest 0.00 di bawah 0.05 yang artinya pembelajaran aktif berpengaruh secara signifikan terhadap hasil belajar dan dapat menjelaskan variasinya sebesar $85.7 \%$. Kesimpulan penelitian ini strategi active learning berbasis web (blended learning) terbukti mampu menciptakan pembelajaran aktif yang berkualitas dan berpengaruh terhadap peningkatan hasil belajar.

Azwar Rhosyied, dan Bambang Wijanarko Otok mengadakan penelitian yang bertujuan mengkaji dampak penggunaan internet sebagai media belajar terhadap prestasi belajar siswa. Sumber data penelitian ini adalah siswa SMA Negeri 1 Probolinggo. Sampel diambil secara random dengan metode sampling stratifikasi 
proporsional berdasarkan kelas. Sebanyak 195 siswa terambil sebagai responden dengan rincian kelas X 69 siswa, kelas XI 69 siswa dan kelas XII 57 siswa. Variabel yang digunakan adalah variabel karakteristik demografi, variabel perilaku penggunaan internet dan 4 variabel laten sebagai input untuk analisis SEM, yaitu Internet sebagai Media Belajar (MI), Motivasi Belajar (MB), Kreativitas (KR), dan Prestasi Belajar (PB). Metode analisis yang dipakai adalah Confirmatory Factor Analysis (CFA) untuk mengkonfirmasi indikator terhadap variabel laten. Model Structural Equation Modeling (SEM) untuk mengetahui besar ukuran pengaruh variabel laten ke variabel laten lain. Hasil yang diperoleh adalah penggunaan internet sebagai media belajar berpengaruh positif terhadap motivasi belajar, kreativitas serta berpengaruh secara tidak langsung terhadap prestasi belajar.

Berdasarkan penelitian terdahulu di atas, peneliti mencoba mengintegrasikan strategi pembelajaran aktif (active learning) dan pembelajaran berbasis internet (internet-based learning) untuk meningkatkan keaktifan dan kreativitas mahasiswa dalam proses pembelajaran.

\section{Metode Penelitian}

Jenis penelitian ini merupakan penelitian deskriptif kualitatif. Adapun yang menjadi subjek dari penelitian ini adalah mahasiswa kelas PG.C semester 4 Prodi PGMI dan dosen yang mengintegrasikan pembelajaran active learning dan internet based learning yaitu, EYW pada mata kuliah Pembelajaran IPA di MI, MSH pada mata kuliah IPS 1 dan ME pada mata kuliah Strategi Belajar Mengajar.

Dalam penelitian ini, instrumen utama adalah peneliti sendiri, karena dalam penelitian jenis kualitatif kehadiran peneliti sebagai instrumen adalah mutlak diperlukan. Peran peneliti adalah sebagai partisipan penuh, bisa juga sebagai pengamat, partisipan dan kehadiran peneliti diketahui sebagai subyeknya. Data dalam penelitian ini adalah interaksi antara dosen dan mahasiswa pada mata kuliah. Sumber data dalam penelitian yaitu subyek dari mana data dapat diperoleh dan sumber data dibagi menjadi 2 yaitu sumber primer dan sekunder. Sumber Primer adalah sumbersumber dasar yang merupakan bukti atau saksi utama dan kejadian yang lalu. Sumber Primer dalam penelitian ini, meliputi: dosen pengampu mata kuliah dan mahasiswa pada prodi PGMI STAIN Ponorogo. Adapun dosen pengampuh mata kuliah yang dijadikan 
sumber primer adalah; 1) MSH pada mata kuliah pembelajaran IPS 1; 2) EYW pada mata kuliah pembelajaran IPA, dan ;3) ME pada mata kuliah Strategi Belajar Mengajar. Sumber Sekunder adalah sumber yang digunakan oleh penulis untuk mendukung dan menunjang pembahasan dalam penelitian ini. Seperti tentang buku active learning dan internet-based learning. Dalam upaya pengumpulan data, peneliti menggunakan beberapa metode yaitu observasi, interview dan dokumentasi.

Dalam proses analisis data, peneliti menggunakan metode analisis kualitatif, yaitu analisis data yang dilaksanakan dengan jalan menggambarkan, melukiskan dan menguraikan secara mendalam keadaan yang sebenarnya di lapangan atau peristiwa yang terjadi. Miles dan Huberman analisis kualitatif meliputi: data collection period, data reduction, data display, and conclussion drawing/verification. Teknik keabsahan data dalam penilaian ini adalah tringulasi data. Menurut Lexy Moleong, tringulasi berupaya untuk mengecek kebenaran data dan membandingkan dengan data yang diperoleh dengan sumber lain, pada berbagai fase penelitian di lapangan, pada waktu yang berlainan dengan tiga macam teknik pemeriksaan yang memanfaatkan penggunaan sumber data, metode, dan teori.

Untuk itu maka peneliti dapat melakukannya dengan jalan mengajukan berbagai macam variasi pertanyaan, mengecek dengan berbagai sumber data atau memanfaatkan berbagai metode agar pengecekan kepercayaan data dalam penelitian dapat dilakukan.

\section{E. Pembahasan}

1. Integrasi Pembelajaran Active Learning dan Internet-Based Learning Prodi PGMI STAIN Ponorogo

Berdasarkan hasil observasi selama proses pembelajaran dan interview terhadap 3 dosen yang mengampuh mata kuliah di Prodi PGMI dapat diketahui bahwa dalam pelaksanaan pembelajaran di kelas dosen menerapkan model pembelajaran active learning untuk mengembangkan kemampuan berpikir analitis mahasiswa dan kapasitas mahasiswa dalam menggunakan kemampuan pada materi-materi kuliah yang diberikan. Di samping itu, pembelajaran internet-based learning diwujudkan dalam bentuk pemakaian situs web seperti yahoo, google, wikipedia, dan youtube untuk 
mendukung proses pembelajaran. Dalam hal ini, internet dipakai baik sebagai media maupun sumber belajar.

Hasil observasi kegiatan pembelajaran pada mata kuliah IPS-1 di kelas PG-C prodi PGMI dengan dosen pengampu MSH pada Senin, 13 Mei 2013 07.00-09.30 pada pokok bahasan Antropologi menunjukkan penerapan model active learning dengan strategi "information search" yaitu suatu cara yang digunakan oleh dosen dengan maksud meminta mahasiswa untuk mencari informasi dengan cara membaca dari berbagai sumber untuk menemukan informasi yang akurat. Adapun langkah-langkah pembelajaran yang diterapkan dalam strategi Information Search adalah:

a. Dosen memberikan apersepsi tentang pengertian dan manfaat antropologi

b. Dosen membagi mahasiswa menjadi 3 kelompok dan diberikan lembar kerja yang berisikan subtopik antropologi

c. Dosen meminta mahasiswa untuk membaca referensi baik dari buku ajar maupun sumber belajar dari internet untuk mencari informasi yang berhubungan dengan subtopik yang terdapat di lembar kerja secara berkelompok.

d. Dosen meminta setiap kelompok untuk mempresentasikan hasil kerja dan memberikan kesempatan bagi kelompok lain untuk memberikan tanggapan.

e. Dosen memberikan penguatan.

Hampir seluruh mahasiswa berpartisipasi aktif dalam diskusi dan mencari informasi untuk mengisi lembar kerja dengan cara mengakses internet baik melalui telepon seluler maupun laptop yang terkoneksi oleh jaringan internet. Sedangkan kreativitas belajar mahasiswa juga muncul pada saat tahap presentasi, yaitu dengan penyampaian ide-ide yang merupakan kombinasi baru berdasarkan data, informasi, atau unsur-unsur yang diperoleh dari hasil membaca dengan menggunakan bahasa yang lugas dan mudah dipahami.

Hasil observasi kedua pada proses pembelajaran mata kuliah IPS-1 dilakukan pada hari Senin, tanggal 27 Mei 2013 pukul 07.00-09.30 di kelas PG-C pada pokok bahasan psikologi sosial, dosen menerapkan model pembelajaran $a c$ tive learning dalam bentuk strategi "Role play", di mana mahasiswa harus membuat skenario yang akan diperankan di depan kelas berdasarkan gambar situasi tentang peristiwa 
psikologi sosial yang terjadi di masyarakat. Adapun langkahlangkah dari Role play sebagai berikut:

a. Dosen memberikan apersepsi tentang peristiwa psikologi sosial

b. Dosen membagi kelas menjadi 5 kelompok

c. Dosen membagikan gambar tentang peristiwa psikologi sosial yang terjadi di Indonesia pada setiap kelompok sebagai acuan pembuatan skenario yang akan ditampilkan di depan kelas.

d. Dosen meminta mahasiswa untuk bermain peran sesuai dengan skenario yang telah dibuat

e. Dosen meminta setiap kelompok untuk memberikan komentar serta konsep psikologi sosial apa yang ingin diangkat dalam tampilan tersebut

f. Dosen memberikan penguatan.

Mahasiswa terlibat aktif dalam pembuatan skenario role play. Mahasiswa sangat antusias untuk bertukar ide dengan kelompoknya tentang bentuk tampilan dari bermain peran. Meskipun, terdapat beberapa mahasiswa yang nampak bercanda dan ada juga mahasiswa yang hanya berdiam saja. Di samping itu, keterampilan mahasiswa untuk memperinci atau mengelaborasi konsep dari psikologi sosial yang terdapat dalam gambar untuk diterjemahkan ke dalam skenario dan tampilan di depan kelas.

Berdasarkan hasil observasi pada proses pembelajaran mata kuliah Strategi Belajar Mengajar pada hari Selasa, tanggal 14 Mei 2013 pukul 07.30-09.00 di kelas PG-C dengan pokok bahasan Pembelajaran Kontekstual/CTL, dosen menerapkan model pembelajaran active learning dalam bentuk strategi "jigsaw" yaitu strategi kerja kelompok yang berstruktur didasarkan pada kerjasama dan tanggung jawab. Prosedur pembelajarannya adalah:

a. Dosen membagi mahasiswa satu kelas dibagi menjadi 4 kelompok sebagai home team.

b. Dosen membentuk 4 tim ahli yang beranggotakan perwakilan dari masing-masing home team.

c. Masing-masing tim ahli mendiskusikan sub topik dari pembelajaran CTL.

d. Setelah selesai berdiskusi dengan tim ahli, mereka kembali ke home team dan secara bergantian mempresentasikan 
hasil diskusinya dengan tim ahli. Home team membuat rangkuman materi berdasarkan keterangan tersebut.

e. Dosen menunjuk beberapa mahasiswa secara acak untuk menjelaskan hasil diskusi dalam home team.

f. Dosen memberikan penguatan.

Keaktifan mahasiswa terlihat selama berdiskusi baik dalam home team maupun dalam tim ahli meskipun terdapat beberapa mahasiswa yang kurang mengikuti kegiatan tersebut. Untuk melengkapi informasi mengenai CTL yang terdapat dalam buku ajar, mahasiswa juga aktif melakukan browsing internet melalui yahoo dan google.

Hasil observasi kedua pada proses pembelajaran mata kuliah Strategi Belajar Mengajar pada hari Selasa, tanggal 21 Mei 2013 pukul 07.30-09.00 di kelas PG-C pada pokok bahasan pembelajaran aktif/active learning. Dosen menggunakan strategi Demonstrasi "Demonstrastion" di mana panduan atau prosedur dari setiap strategi mengenai model pembelajaran aktif telah diupload di internet melalui platform Edmodo. Langkah-langkah pembelajarannya adalah sebagai berikut:

a. Dosen melakukan curah pendapat tentang model-model pembelajaran.

b. Dosen membagi mahasiswa menjadi 10 kelompok dalam platform Edmodo dan meminta mahasiswa untuk mengaksesnya melalui jaringan internet

c. Dosen membagikan lembar kerja yang berisikan langkahlangkah pembelajaran aktif yang telah diuplod di Edmodo dan meminta mahasiswa untuk mengunduhnya.

d. Dosen meminta mahasiswa mendiskusikan langkah-langkah pembelajaran tersebut dan dipraktekkan dalam kelas dalam bentuk "demonstration".

e. Setiap kelompok melakukan demonstrasi strategi dalam model pembelajaran active learning

f. Dosen beserta mahasiswa memberikan komentar dan feedback

g. Dosen memberikan penguatan

Mahasiswa berpartisipasi aktif dalam sharing ide untuk memahami strategi yang akan didemonstrasikan. Mahasiswa juga sangat kreatif dalam penggunaan media maupun materi 
yang menarik tentang pembelajaran di MI yang mereka unduh dari internet.

Hasil observasi proses pembelajaran Mata Kuliah Pembelajaran IPA di MI dengan pokok Bahasan Pembelajaran Materi Struktur Bumi dan Batuan di MI di kelas PG-C dengan dosen Pengampuh EYW dilaksanakan pada hari Kamis, tanggal 16 Mei 2013 pukul 09.00-10.30 dengan menggunakan model active learning dengan strategi concept mapping sebagai cara yang digunakan oleh dosen dengan maksud meminta mahasiswa untuk membuat konsep atau kata-kata kunci dari suatu pokok persoalan sebagai rumusan inti pelajaran. Di samping itu, dosen juga mengundur berbagai gambar melalui google sebagai media untuk apersepsi. Adapun langkah-langkah pembelajarannya sebagai berikut:

a. Dosen memberikan apersepsi tentang Materi Struktur Bumi dan Batuan

b. Dosen membagi kelas menjadi 12 kelompok.

c. Dosen membagikan kertas plano dan spidol warna-warni sebagai lembar kerja untuk membuat peta konsep.

d. Dosen meminta mahasiswa untuk bekerjasama dalam kelompok menuangkan ide dalam bentuk peta konsep berdasarkan subtopik yang telah ditentukan.

e. Dosen meminta setiap kelompok untuk mempresentasikan peta konsep yang dibuat di kertas plano.

f. Dosen memberikan kesempatan kepada kelompok lain untuk memberikan komentar.

g. Dosen memberikan penguatan.

Mahasiswa aktif terlibat untuk berdiskusi guna membuat peta konsep yang menarik pada kertas plano dan browsing melalui internet untuk mencari informasi yang sesuai dengan topik yang diberikan. Kreativitas mahasiswa dapat dilihat dalam tampilan di depan kelas dengan peta konsep yang dibuat sangat menarik dan atraktif.

Hasil observasi kedua pada proses pembelajaran mata kuliah Pembelajaran IPA di MI dilakukan pada hari Kamis, tanggal 30 Mei 2013 pukul 09.00-10.30 di kelas PG-C dengan pokok Bahasan Pembelajaran Matahari sebagai pusat Tata Surya menunjukkan bahwa dosen menerapkan strategi peer teaching yang merupakan latihan mengajar yang dilakukan 
oleh mahasiswa kepada teman-teman mahasiswa lain, dengan prosedur sebagai berikut:

a. Dosen memberikan apersepsi dengan menggunakan media video dan gambar tentang sistem tata surya.

b. Dosen membagi kelas menjadi 2 kelompok

c. Dosen menjelaskan bahwa mahasiswa harus berlatih menjadi guru untuk menjelaskan materi yang telah ditentukan

d. Setiap kelompok harus menunjuk 3 anggota kelompoknya untuk menjelaskan dan anggota kelompok lain menjadi pengamat dan siswa.

e. Dosen dan beberapa mahasiswa memberikan komentar atas tampilan tersebut.

f. Dosen memberikan penguatan

Media yang dipakai adalah video yang disajikan menggunakan LCD. Video tersebut tentang proses gerhana bulan dan matahari yang diunduh lewat internet tepatnya di youtube. Kreativitas mahasiswa terlihat saat menjelaskan dengan bantuan media video tersebut. Di sisi lain, mahasiswa juga berperan aktif baik sebagai guru, pengamat dan mahasiswa selama proses peer teaching.

2. Faktor Pendukung dan Penghambat Pembelajaran active learning dan internet-based learning Prodi PGMI STAIN Ponorogo

Berdasarkan hasil observasi kegiatan yang mengintegrasikan pembelajaran active learning dan internet-based learning serta wawancara kepada 3 dosen pada prodi PGMI dapat diketahui beberapa faktor pendukung dan penghambat selama proses pembelajaran.

a. Faktor Pendukung integrasi pembelajaran active learning dan internet-based learning

Pertama, perlunya mempertimbangkan strategi pembelajaran pada model active learning. Setiap strategi pada pembelajaran active learning memerlukan persiapanpersiapan yang berbeda tingkat kemudahannya begitu pula dalam pelaksanaannya. Oleh sebab itu, perlu dipertimbangkan dengan baik strategi yang akan dipergunakan. Beberapa hal yang dapat dijadikan pertimbangan dalam memilih strategi pembelajaran adalah tujuan pembelajaran, 
aktivitas, pengetahuan awal mahasiswa, alokasi waktu dan sarana penunjang.

Kedua, Memberikan pengarahan yang jelas, dikarenakan sebagian besar strategi dalam model pembelajaran $a c$ tive learning adalah kerjasama untuk berdiskusi dalam kelompok, maka diskusi dalam kelas merupakan tanggung jawab dosen untuk menjaganya dalam alur dan tempo yang baik, sehingga pengarahan yang singkat dan jelas mempengaruhi kesuksesan setiap proses pembelajaran.

Ketiga, motivasi belajar mahasiswa yang tinggi, motivasi memegang peranan penting dalam kegiatan pembelajaran. Kegiatan pembelajaran active learning akan berhasil baik jika mahasiswa memiliki motivasi yang tinggi dalam belajar. Di samping itu, motivasi belajar yang tinggi akan mendorong mahasiswa untuk aktif berpartisipasi pada pembelajaran dalam setiap strategi dalam model active learning supaya mahasiswa dapat memperoleh hasil pembelajaran secara efektif dan optimal.

Keempat, ketersediaan sarana dan prasarana yang memadai, dikarenakan kegiatan pembelajaran dilakukan melalui pemanfaatan jaringan internet, maka dibutuhkan jaringan yang kuat sehingga mahasiswa dapat mengkases informasi secara cepat. Di samping itu, ketersediaan perangkat lain seperti laptop, LCD serta media pendukung lainnya juga sangat diperlukan.

b. Faktor Penghambat integrasi pembelajaran active learning dan internet-based learning

Pertama, keterbatasan waktu, konsep dasar dari pembelajaran active learning adalah segala bentuk pembelajaran yang memungkinkan mahasiswa berperan secara aktif dalam proses pembelajaran itu sendiri baik dalam bentuk interaksi antar mahasiswa maupun mahasiswa dengan dosen dalam proses pembelajaran tersebut. Sehingga, dibutuhkan waktu yang cukup panjang agar seluruh mahasiswa dapat berpartisipasi aktif. Dalam perkuliahan diberikan waktu 90 menit pada setiap pertemuan. Sehingga dengan waktu 90 menit dan jumlah mahasiswa sebanyak 31, para dosen sering mengeluhkan tentang hal tersebut. Apalagi bila ada penataan ruang 
belum terkondisi dengan baik untuk kerja kelompok, sehingga perlu waktu merubah posisi yang dapat juga menimbulkan gaduh.

Kedua, dominasi mahasiswa yang pintar. Pembelajaran active learning ditujukan agar mahasiswa secara aktif bertanya dan menyatakan pendapat dengan aktif selama proses pembelajaran, sehingga saat berdiskusi kelompok nampak hanya beberapa mahasiswa yang mendominasi untuk aktif menyatakan pendapat. Hal yang paling mencolok lainnya adalah ketika diminta perwakilan dari kelompok untuk presentasi di depan kelas, mahasiswa yang menjadi penyaji hampir selalu sama yaitu mahasiswa yang masuk kategori pintar saja. Kebanyakan mahasiswa masih ragu-ragu dan belum percaya diri untuk belajar kelompok serta mengungkapkan pendapat.

Ketiga, ketidaksiapan mahasiswa dalam menerima materi baru, Pembelajaran active learning memiliki konsekuensi pada mahasiswa untuk mempersiapkan diri dengan baik di luar jam kuliah. Mahasiswa memiliki tanggungjawab yang besar untuk mencari seluas-luasnya materi yang melatarbelakangi perkuliahan sehingga dapat berpartisipasi dengan baik dalam perkuliahan. Tetapi, pada taraf praktek di dalam kelas, sebagian mahasiswa tidak siap dalam menerima materi baru yang disampaikan melalui strategi active learning karena mereka kurang mempersiapkan diri di luar jam kuliah meskipun pada saat awal kuliah atau pada saat menjelaskan CO mahasiswa telah diberi penjelasan apa yang akan dilakukan selama proses pembelajaran.

\section{F. Penutup}

Integrasi pembelajaran active learning dan internet-based learning yang dapat meningkatkan keaktifan dan kreativitas belajar mahasiswa di Prodi PGMI STAIN Ponorogo dalam bentuk penggunaan strategi pembelajaran yang mengembangkan kemampuan berpikir analitis dari mahasiswa yaitu information search dan role play pada mata kuliah IPS1, Jigsaw dan demonstration pada mata kuliah Strategi Belajar Mengajar, concept mapping dan peer teaching pada mata kuliah Pembelajaran IPA di MI. Di samping itu, untuk mendukung proses pembelajaran, baik dosen maupun mahasiswa memanfaatkan situs 
web seperti yahoo, google, wikipedia, youtube dan edmodo. Dalam hal ini, internet dipakai baik sebagai media maupun sumber belajar.

Faktor pendukung integrasi pembelajaran active learning dan internet-based learning di antaranya perlunya mempertimbangkan strategi pembelajaran pada model active learning, pemberian pengarahan yang jelas, motivasi belajar mahasiswa yang tinggi dan tersedianya sarana dan prasarana pembelajaran. Sedangkan faktor penghambat integrasi pembelajaran active learning dan internet-based learning adalah keterbatasan waktu, dominasi mahasiswa yang pintar dan ketidaksiapan mahasiswa dalam menerima materi baru.

\section{Kepustakaan}

Bonwell, C.C., Active Learning: Creating Excitement In The Classroom, Center for Teaching and Learning: St. Louis College of Pharmacy, 1995.

Carrolina, Donna, Penerapan Strategi Active Learning Berbasis Web (Blended Learning) Dalam Upaya Menciptakan Pembelajaran Aktif Dan Pengaruhnya Terhadap Hasil Belajar, (Online) http://journal.unnes.ac.id/sju/index.php/ eeaj/article/view/559, diakses pada 29 April 2013.

Effendi, Mukhlison, Silabus Strategi Pembelajaran, PGMI, 2012.

Hadi, Sutrisno, Metodologi Penelitian, Yogyakarta: Ardi Ofset, 1989.

Hartanto, Antonius \& Onno W. Purbo, E-Learning Berbasis PHP dan MySQL, Jakarta: Elex Media Komputindo, 2002.

Horton, William \& Katherine Horton, E-Learning Tools and Technologies: A consumer Guide for Ttrainers, Teachers, Educators, and Instructional Designers, USA: Wiley Publishing, 2003.

Mahmudah, Umi, Active Learning dalam Pembelajaran Bahasa Arab, Malang: UIN-Malang Press, 2008.

Moleong, Lexy, Metodologi Penelitian Kualitatif, Bandung: Remaja Rosdakarya, 2006.

Munandar, Utami, Pengembangan Kreatifitas Anak Berbakat, Jakarta: Rineka Cipta, 2004. 
Munir, Kurikulum Berbasis Teknologi Informasi dan Komunikasi, Bandung: Alfabeta, 2008.

Nasution, Metode Research, Jakarta: Bumi Aksara, 1996.

Nazir, Mohammad, Metode Penelitian, Jakarta: Ghalia Indonesia, 1988.

Ngalim Purwanto, Psikologi Pendidikan, Bandung: Remaja Rosdakarya, 2003.

Purwadarminta, Kamus Umum Bahasa Indonesia, Jakarta: Balai Pustaka, 1986.

Sanjaya, Wina, Pembelajaran dalam Implementasi Kurikulum Berbasis Kompetensi, Jakarta: Kencana, 2008.

Siahaan, Sudirman, E-Learning (Pembelajaran Elektronik) sebagai Salah Satu Alternatif Kegiatan Pembelajaran, Jurnal Pendidikan,(Online), 2002.

Silberman Mel, Active Learning 101 Strategis to Teach Any Subject,: YAPPENDES, 1996.

Slameto, Belajar dan Faktor-faktor yang Mempengaruhinya, Jakarta: Rineka Cipta, 2003.

Soekartawi, Prinsip Dasar E-Learning: Teori Dan Aplikasinya Di Indonesia, Jurnal Teknodik, Edisi No.12/VII/Oktober/2003, 2003.

Sopian, Ahmad, Peran Pendidik dalam Proses Belajar Mengajar Melalui Pengembangan e-Learning (Online)media.diknas.go.id/media/document/5084.pdf, diakses pada 29 April 2013.

Sriyono dkk, Teknik Belajar Mengajar Dalam CBSA, Jakarta: ineka Cipta, 1992.

Sudjana, Nana, Metode Statistika, Edisi Ke 6, Bandung: Tarsito, 1996.

Sugandi A, dkk, Belajar dan Pembelajaran, Semarang: IKIP PRESS, 2000.

Tanti, Puput Dwi Maret, Penerapan Pembelajaran Aktif (Active Learning) Dengan Metode Mind Map Untuk Meningkatkan Kreativitas Belajar Biologi Siswa Kelas XI A3 SMA Negeri 1 Ngemplak Boyolali, Surakarta: FKIP Universitas Sebelas Maret, 2012.

Yasin, Fatah, Dimensi-dimensi Pendidikan Islam, Malang: UIN Malang Press, 2008.

Zaini, Hisyam dkk, Strategi Pembelajaran Aktif, Yogyakarta: CTSD IAIN Sunan Kalijaga, 2004. 
308 | Mukhlison Effendi

(Online)http://edweb.sdsu.edu/people/bdodge/Active/ActiveLearni ng.html, diakses pada 29 April 2013. 
